\title{
Pre-service Teachers Perceptions' of Tutoring Program: Case Study of Teacher College Model in Mauritania
}

\author{
Mohamed Leghdaf Abdellahi ${ }^{1}$, Endale Tadesse ${ }^{2}$, Sabika Khalid ${ }^{2}$ \\ ${ }^{1}$ Ph.D. Candidate at Faculty of Education, Southwest University, China \\ ${ }^{2}$ Ph.D. Candidate at Faculty of Education, Southwest University, China \\ ${ }^{3}$ Ph.D. Candidate at Faculty of Education, Southwest University, China
}

\begin{tabular}{|c|c|}
\hline Articl & Abstract \\
\hline $\begin{array}{l}\text { Article history: } \\
\text { Received: } 16 \text { September } 2020 \\
\text { Revised: } 27 \text { October } 2020\end{array}$ & $\begin{array}{l}\text { Purpose: The main objective of this study is to investigate the perceptions of } \\
\text { pre-service teachers regarding their tutoring program at teacher college } \\
\text { model in Mauritania. }\end{array}$ \\
\hline Acc & $\begin{array}{l}\text { Approach/Methodology/Design: Explanatory Sequential design was } \\
\text { adopted. Hence, a survey questionnaire and interviews were developed to }\end{array}$ \\
\hline Teachers, & $\begin{array}{l}\text { gather data from } 80 \text { pre-service teachers, } 20 \text { in-service teachers, and } 2 \\
\text { mentors. }\end{array}$ \\
\hline $\begin{array}{l}\text { Tutoring program, } \\
\text { Teacher College Model, } \\
\text { Assessment }\end{array}$ & $\begin{array}{l}\text { Findings: The findings of the study revealed that internship training has a } \\
\text { significant impact on the development of pre-service teachers, but the } \\
\text { teacher trainees did not get enough time for internship training sessions due } \\
\text { to the workload of the theoretical courses. Mentors and management }\end{array}$ \\
\hline ype : & $\begin{array}{l}\text { support were found insignificant to the development of teacher college } \\
\text { model trainees. }\end{array}$ \\
\hline Research Article & $\begin{array}{l}\text { Practical Implications: The study provides a systematic evaluation of the } \\
\text { current in-service teacher training programs. It reflects certain aspects of }\end{array}$ \\
\hline Correspon & \\
\hline $\begin{array}{l}\text { Mohamed Leghdaf Abdellahi } \\
\text { Email: } \\
\text { leghdafmohamed@yahoo.com }\end{array}$ & $\begin{array}{l}\text { Originality/value: Teacher College Model has to adjust the levels of its } \\
\text { tutoring where the study found that teacher trainees suffer the short-term } \\
\text { practicum while they are complaining about the workload of coursework. } \\
\text { Another way of the assessment regarding the tutoring program could be } \\
\text { including observation. It is suggested that a qualitative study where } \\
\text { researchers can spend more time at the teacher college model and with } \\
\text { teaching staffobserving the different aspects of the tutoring program. }\end{array}$ \\
\hline
\end{tabular}

\section{Introduction}

Teachers are the backbone of any education system, and investment in teacher education is a mandatory process for the quality of education in the $21^{\text {st }}$ century (Katitia, 2015). In this case, the procurement of Education for All (EFA) objectives and Millennium Development Goals (MDGs) pose a challenge for the initiatives of teacher education. The challenges demand supporting teacher education colleges with resources to facilitate the training for pre-service teachers to overcome the shortage of teaching skills and to powerfully prepare them to grow up with teaching experience before they confined to schools for the teaching profession.

The task requires grounding measures to support teacher education preparation programs to sustain the development of trainee teachers in terms of quantity and quality of pre-service 
tutoring programs trainee teachers get involved in during the pre-service preparation (Sinyolo, 2007). According to UNESCO statistics 2016, 69 million teachers would be needed worldwide to deliver education at both primary and secondary levels by 2030. Africa continent is the region where a significant part of the mentioned number said to be needed. Statistics from UNESCO 2016 believed that poor quality of teacher training and teachers' shortage are critical issues among Sub-saharan countries. The data reported that approximately 17 million trainee teachers would be required to join teacher colleges for training by 2030 to enhance education for students (UNESCO, 2016).

In Mauritania, the emergence of the pre-service teaching education is dated to the postcolonial period when the government declared the foundation of teacher training centres in the 1970s under decree No. 261/70. These teacher college institutions are controlled and working under the authority of the ministry of higher education. Consequently, several policies were initiated to regulate teacher education programs in Mauritania. In first, preservice tutoring programs were formulated to take a period of four years, and the certificate of the upper secondary level was considered to be a maximum academic level the applicant needs to join the pre-service teaching program for the secondary level. To give more credibility to teaching quality, the ministry of higher education has made a reform in 2004 regarding qualifications to access teacher education colleges. The new reform has abstracted the duration of the pre-service teaching program from four years to two years but, it imposes a DUG certificate as a minimum academic level; two years of university-level to be eligible for enrolment at a teacher training centre (MoHE, 2018). The current study aims to probe perceptions of pre-service teachers regarding their tutoring program to see whether the program is practically fulfilling the needs of teacher trainees.

\section{Literature Review}

Nowadays, teacher education colleges are considered the main supplier for teachers through the preparation programs provided for trainee teachers at the preparation level before starting the teaching profession. Principally, the training program for pre-service teachers executed within two stages of learning. The first stage is named theoretical course while the second one is called practicum learning. The implementation of pre-service education stages varies from one country to another. Some teacher education colleges offer practicum learning at the same time student- teachers are attending theoretical coursework. On the other hand, other colleges give practicum learning sessions in a separate semester or a year, and this used to be in the last years of the training program. In Mauritania, the preparation of pre-service teachers is the most prevalent process of learning for student teachers' education. Pre-service teachers are enrolled at Teacher College to take pre-service tutoring program with the aim of getting a national teaching certificate (NCTC). Therefore, the tutoring program is a process to ameliorate trainee teachers' learning to acquire the needed teaching competency to lead the teaching process in the schools. (Mathekga, 2004).

Pre-service teachers' preparation programs offered at teacher education colleges are meant for prospective teachers to grant them with knowledge and teaching competencies obligated for a 
teaching job (Akbar, 2002). Teacher college model stands for the central school forming preservice teachers to serve as teachers at public schools in Mauritania. Literature review shows that only higher education institutions that introduce tutoring programs to pre-service teachers have the aptitude to equip trainee teachers with teaching competency throughout micro teaching activities. According to Alsup (2006), the educational organizations that train candidate teachers are the source of change, where it can influence students learning and the success of the education system. The tutoring programs pre-service teachers receive at teacher colleges is a vital strand to quid trainee teachers to subsume teaching methods (Alsup, 2006).

In contrary view to Alsup, Darling-Hammond (2009) argued that many of teacher education programs provided at teacher colleges demoted to provide trainee teachers with meaningful "field-based skills". In this concern, teacher college model was found in Mauritania for the sake to support the development of teacher trainees' knowledge and practices through a curriculum of education is abstracted in the pre-service tutoring program. The mission of teacher college model is to cater teacher trainees with knowledge and teaching skills to improve education quality and students' academic achievement. Yet, recent data shows there is a going down of students' scores in the national exams such as BEPC and NBC based on the 2015 report conducted by the ministry of education. Students passing rate of secondary national exams is illustrated in the bellow table:

Table1: Students passing rate of National exams (BEPC\&NBC)

\begin{tabular}{lccccc}
\hline Education level & $\begin{array}{c}\text { Exam } \\
\text { type }\end{array}$ & $\mathbf{2 0 1 2}$ & $\mathbf{2 0 1 3}$ & $\mathbf{2 0 1 4}$ & $\mathbf{2 0 1 5}$ \\
$\begin{array}{l}\text { Lower } \\
\text { BEPC }\end{array}$ & $45 \%$ & $36 \%$ & $30 \%$ & $28 \%$ \\
$\begin{array}{l}\text { Secondary level } \\
\text { Upper }\end{array}$ & NBC & $18 \%$ & $17 \%$ & $13 \%$ & $12 \%$ \\
Secondary level & & & & & \\
\hline
\end{tabular}

Source: Ministry of Education 2015.

Proceeding from 2015 report, the study wanted to investigate preservice teachers tutoring program to find out whether teacher trainees gain adequate competency before they join teaching as a profession. In a study, Hattie (2009) found that the way teachers perform in the classroom is strongly influencing students learning and their academic scores. Hattie mentioned that teaching demands the teacher trainees to be well prepared before getting to the teaching profession. Also, Palardy et al. (2008) argued that teachers with intensive training are always associated with better student achievement, and pre-service education is a program which teacher trainees engage to develop their teaching competency.

Like the previous studies, (Dawud, 2005; Sina \& Vathiya 2006; \& Kruijer, 2010) believe that pre-service tutoring programs are learning stages of imparting knowledge and skills to teacher trainees. Therefore, from the highlighted literature the study emerged to investigate pre-service teachers' preparation program from pre-service and in-service teachers point of views to identify whether the program is adequately enough to grant pre-service teachers with 
knowledge and skills to develop their teaching performance. As a result of many efforts and investments pioneered by the government of Mauritania, teacher college model was established to prompt education quality in the country. So, the teacher college existed for educating teacher trainees and equipping them with teaching competencies which teachers need for teaching in different public schools in Mauritania. The study would be significant because it is the first study in the country conducted to investigate pre-service teachers tutoring programs at teacher college Model College. Till now, there is no known research has been done yet to study this specific topic in the context of Mauritania since teacher college model started to provide pre-service teachers tutoring programs (PTP).

The findings of this research will assist in offering meaningful data about the framework of pre-service teachers' training program in Mauritania. The study would also help some researchers, policymakers and even stakeholders who are interested in searching, promoting and developing the area of teacher education programs in the country purposely for enriching and developing these training programs to meet the teachers' needs to increase their teaching competency for facing 21-century teaching challenges in Mauritania.

Situated learning theory was chosen to be adapted as a lens to quid this study. The theory is an educational theory adopted from Lave \& Wenger, 1991. The main argument of situated learning theory is that community of learning is a proper environment where trainees dispose to learn. The learning community offers learners the opportunity to get involved in the learning process throughout the active participation in the undertaken activities. So, community of practice is the better place where learners such as teacher trainees can get a chance to improve knowledge and skills. Due to learners' active participation, which Lave and Wenger have underlined in the situated learning theory. The more trainees are exposed to the opportunities to practice throughout the community of practice is the more to better their competency. Therefore, the researcher used situated learning theory as a framework because this theory suits for teacher trainees to get engaged in learning through the field practice. The theory argues that learners should engage in the community of practice to develop their knowledge throughout training activities where Lave \& Wenger (1991, p. 184) declared that "situated learning places learning in the context in which it will later be applied...it facilitates the transfer of learning to new situations"(p,184).

\section{Methodology and Procedures}

This section outlines the research methodology that was employed to examine the questions posed in this study. On the other hand, the chapter also provides reasons to justify the choice of the particular research design for the data collection. The analysis process and interpretations of the data is also prescribed in this section.

\subsection{Research Design}

Explanatory sequential design was used as method to gather the data required for this research as well as designed in the below figure: 
Explanatory sequential design

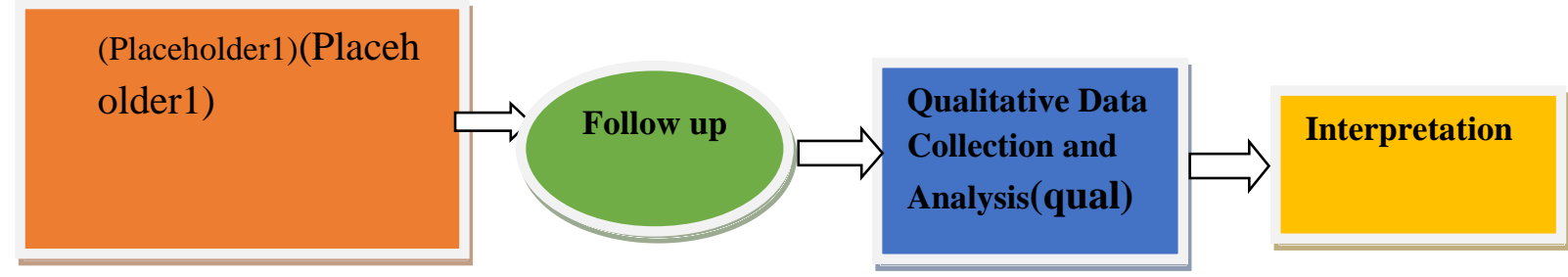

Source: (Creswell, 2014)

\subsection{Participants and sampling of the study}

This study targeted individuals involved in the pre-service teachers' tutoring program at teacher college model. Meaning that all participants experienced the same tutoring program, whether they are pre-service or in-service teachers. The study also included two mentors who supervised pre-service teachers during the duration of the tutoring program. According to the policy of teacher education model, every year only 200 students are allowed to have access to enrol for the two-years tutoring program at teacher education model. This implies that teacher college model has currently 400 pre-service teachers registered for the academic year 2018 and 2019 when this study was conducted. Student teachers or teacher trainees were divided to grade 1 and grade 2 . So, the study mainly targeted 200 teacher trainees who were in grade 2 and preparing to complete their last months of the tutoring program. A sample of 100 participants was selected randomly from the total population to respond to the survey questions. The sampling technique divided as 80 pre-service and 20 in-service teachers. The researcher also selected two (2) mentors purposively for interview.

\subsection{Data collection}

The main data of this study was collected through a survey questionnaire. The questionnaire consisted of 25 statements designed by the researcher based on the revised literature and aspects related to pre-service teachers tutoring programs. Ordinal Five Liker-scale was used to measure participants' responses on the survey questions. Likert-scale was ranged from 1(Strongly Disagree), 2(disagree), 3(neutral), 4(agree) and 5(strongly agree). Then, semistructured interviews were conducted with two mentors and two in-service teachers. Interviews data was collected to supplement quantitative finding.

\section{Results and Discussion}

Firstly, the researcher employed the descriptive and inferential analysis method to get the numerical findings that could lead to constructing the qualitative design. The researcher followed coding data procedures as a way to organize the data obtained from the survey 
questionnaire. Secondly, the researcher analyzed the data to define the mean and standard deviations statistically to interpret results accordingly. SPSS software was used to calculate the mean and standard deviations for the quantitative data. The researcher also applied qualitative procedures such as transcription and description of the interviews utilized to summarize and identify themes obtained from the form interviews.

\section{Findings of the study}

Because of the study design, the main findings regarding teacher college model tutoring program were obtained from the survey.

\subsubsection{Descriptive analysis of theoretical coursework}

The bellow table number 2 summarizes the overall perceptions of teacher college model trainees towards theoretical coursework.

$$
(\mathrm{M}=0.9878, \mathrm{SD}=0.8653)
$$

Table 2: Perceptions towards Theoretical Coursework

\begin{tabular}{llllll}
\hline & $\mathrm{N}$ & Minimum & Maximum & Mean & Std. Deviation \\
Mean_Theoretical_Courses & 100 & 2.50 & 5.00 & 3.5625 & .56282 \\
Valid N(listwise) & 100 & & & & \\
\hline
\end{tabular}

Source: Authors

Observations from table2 reveal that the overall across $(\mathrm{N}=100)$ participant was $(\mathrm{M}=3.56)$ with a standard deviation of 0.56 respectively.

\subsubsection{Descriptive analysis of Internship Training}

Table 2: Internship Training

\begin{tabular}{llllll}
\hline & N & Minimum & Maximum & Mean & Std. Deviation \\
Mean_Practicum_Training & 100 & 2.00 & 5.00 & 3.6080 & .71176 \\
Valid N(listwise) & 100 & & & & \\
\hline
\end{tabular}

Source: Authors

Table number3 explains the overall mean score and standard deviation regarding participants' perceptions of the internship training $(M=3.60$ with $S=0.71)$.

\subsubsection{Descriptive analysis of Mentors Support}

Table 4: Descriptive analysis of Mentors and Management Support

$\begin{array}{llll} & \text { N } & \text { Mean } & \text { Std. Deviation } \\ \text { Mean_Mentors_Support } & 100 & 3.2650 & .59440\end{array}$




Valid N (listwise) 100

Source: Authors

Table 5: Management Support

\begin{tabular}{llll}
\hline & N & Mean & Std. Deviation \\
Mean_Managemental_Suppo & 100 & 3.2825 & .60135 \\
rt & & & \\
Valid N (listwise) & 100 & &
\end{tabular}

Source: Authors

Table 4 and 5 display the overall descriptive statistics regarding participants' perceptions of mentors' and management support. Based on the above tables, the mean score across $(\mathrm{N}=100)$ participants' responses on mentors' support was 3.26 with $\mathrm{S}=0.59$ while it was 3.28 with 0.60 for responses management support.

\subsubsection{Inferential Analysis}

\subsubsection{Independent t-test analysis based on participants' profession}

Table 6: Independent Samples Test

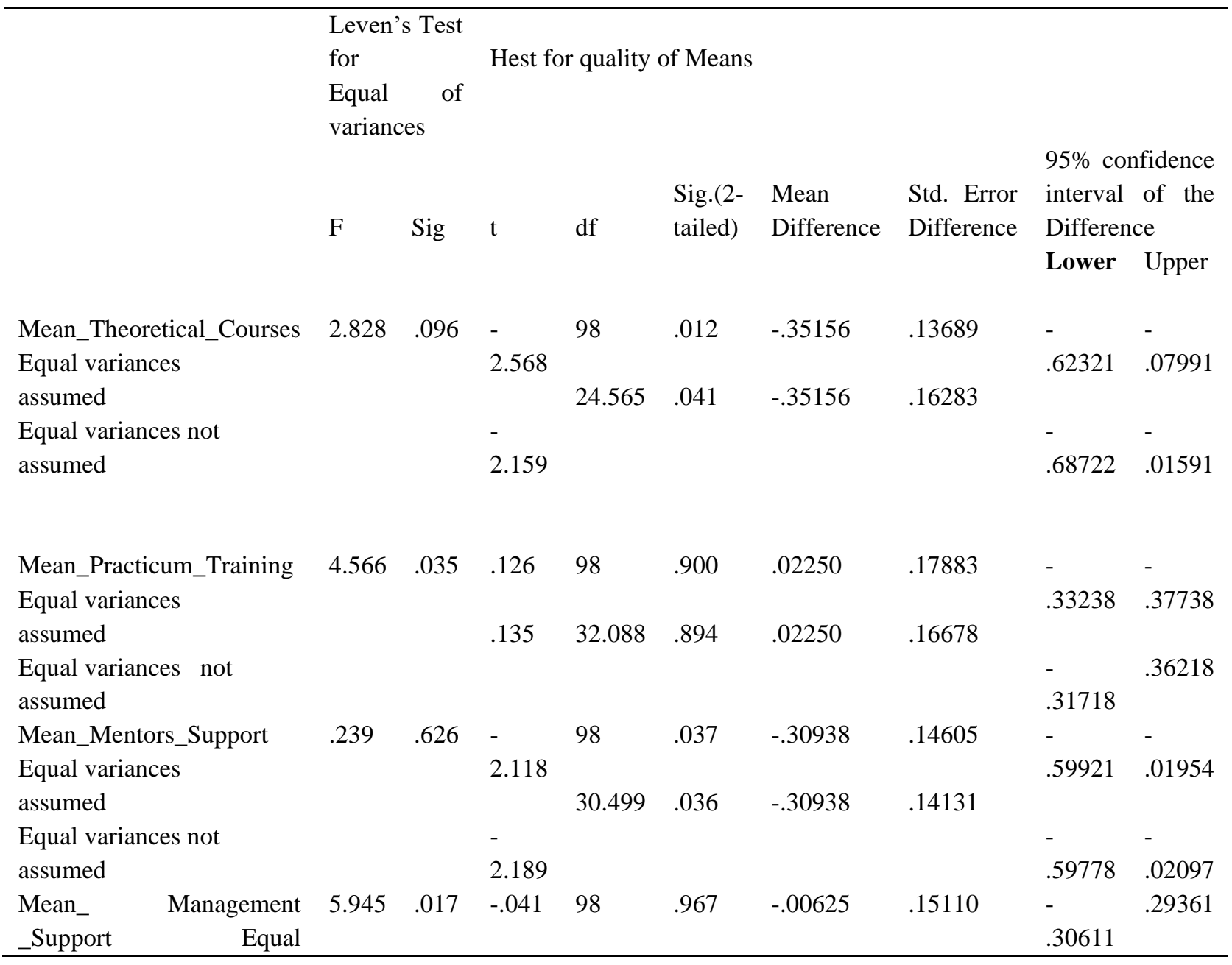




\begin{tabular}{|c|c|c|c|c|c|c|}
\hline variances assumed & -.050 & 38.775 & .961 & -.00625 & .12569 & .24803 \\
\hline Equal variances not & & & & & & \\
\hline assumed & & & & & & \\
\hline
\end{tabular}

Source: Authors

T-test analysis in table6shows there is a significance difference of mean $(\mathrm{p}<0.05)$ among participants' perceptions of theoretical coursework and mentors' support. $\mathrm{P}$ value was 0.01 and 0.03 regarding pre-service and in-service teachers' perceptions of theoretical coursework and mentors support. On the other hand, the t-test displays there is no significance difference among pre-service and in-service teachers' perceptions regarding internship training and management support( $\mathrm{P}>0.05)$.

\subsubsection{Independent T-test Analysis Based on Gender Factors}

Table 7: Independent Samples Test

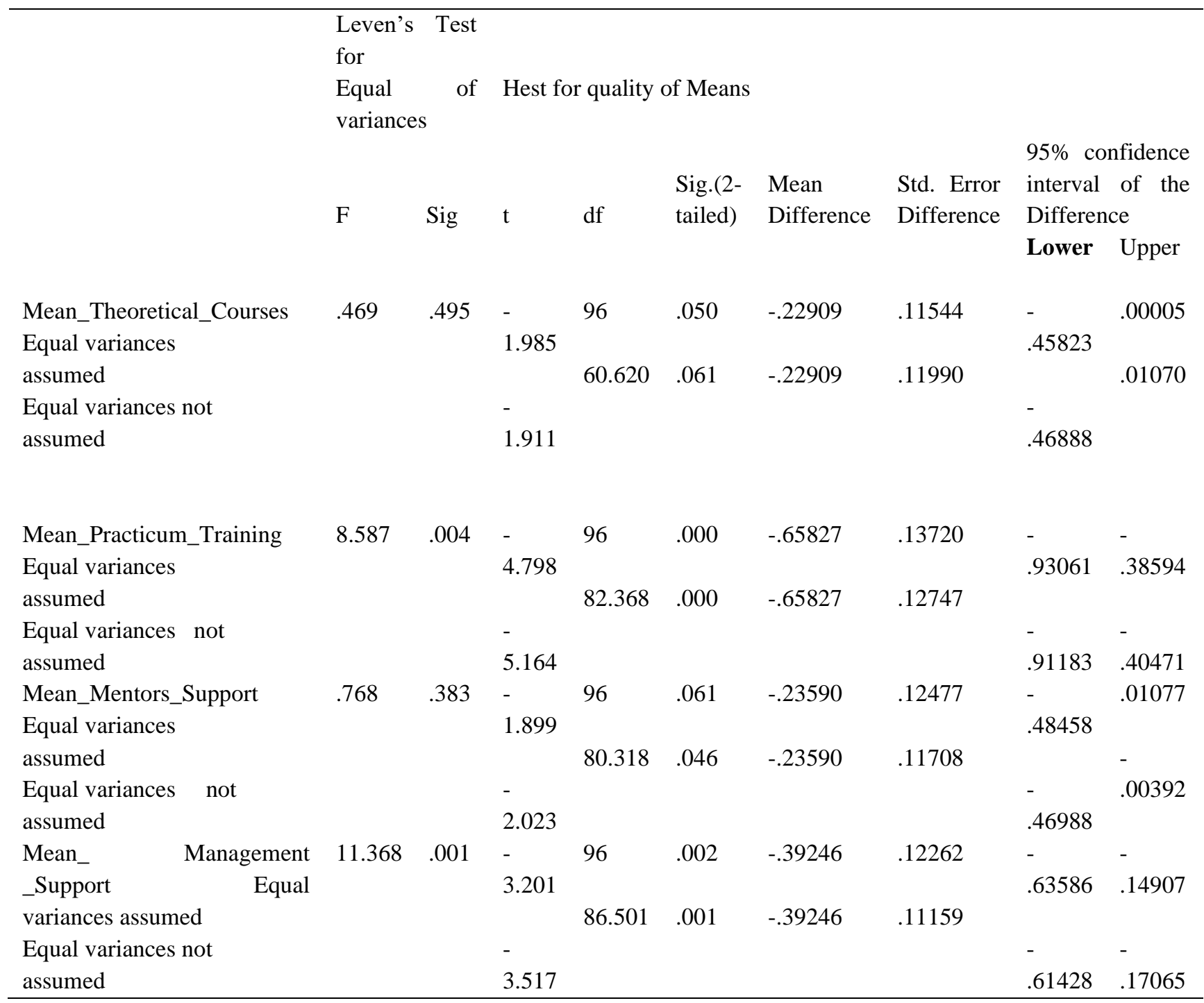

Source: Authors 
T-test analysis in table7 demonstrates there is no significance difference between female and male participants' points of view regarding theoretical coursework and mentors' support $(\mathrm{p}>0.05)$. Regarding male and female participants' perception of internship training and management support, the t-test analysis discloses there is a high significant mean difference among participants. The level of $\mathrm{P}$-value was $(\mathrm{p}<0.05)$.

\subsubsection{Comparing Participants Perception Based on Age Factor}

\begin{tabular}{|c|c|c|c|c|c|c|c|}
\hline \multicolumn{8}{|c|}{ Table 8: ANOVA } \\
\hline & & \multicolumn{2}{|l|}{ Sum } & \multicolumn{4}{|l|}{ Mean } \\
\hline & & Squares & df & Square & $\mathrm{F}$ & Sig. & \\
\hline \multirow[t]{4}{*}{ Mean_Theoretical_Courses } & Between & 2.737 & 3 & .912 & 3.061 & & .032 \\
\hline & Groups & & & & & & \\
\hline & Within Groups & 28.622 & 96 & .298 & & & \\
\hline & Total & 31.359 & 99 & & & & \\
\hline \multirow[t]{4}{*}{ Mean_Practicum_Training } & Between & .958 & 3 & .319 & .623 & & .602 \\
\hline & Groups & & & & & & \\
\hline & Within Groups & 49.195 & 96 & .512 & & & \\
\hline & Total & 50.154 & 99 & & & & \\
\hline \multirow[t]{4}{*}{ Mean_Mentors_Support } & Between & .698 & 3 & .233 & .652 & & .584 \\
\hline & Groups & & & & & & \\
\hline & Within Groups & 34.279 & 96 & .357 & & & \\
\hline & Total & 34.978 & 99 & & & & \\
\hline Mean_Managemental_Suppor & Between & 3.526 & 3 & 1.175 & 3.496 & & .019 \\
\hline \multirow[t]{3}{*}{$\mathrm{t}$} & Groups & & & & & & \\
\hline & Within Groups & 32.275 & 96 & .336 & & & \\
\hline & Total & 35.801 & 99 & & & & \\
\hline
\end{tabular}

Source: Authors

From this table8, the One-way ANOVA analysis accounts there is statistically a significance of mean difference among respondents' perception of theoretical coursework and management support based on the age factor, the $p$ - value was ( $>0.05)$. Conversely, ANOVA analysis indicate there is no significance difference among participants perceptions of practicum training and mentors' support based on age group factor $(\mathrm{p}<0.05)$.

\subsubsection{Comparing Participants Perceptions based on Education Background}

\begin{tabular}{lllllll}
\hline & \multicolumn{3}{c}{ Table 9: ANOVA } & & & \\
& & Sum of Squares & df & Mean Square & F & Sig. \\
Mean_Theoretical_Courses & Between & 1.374 & 3 & .458 & 1.467 & .229 \\
& Groups & & & & & \\
& Within Groups & 29.985 & 96 & .312 & & \\
& Total & 31.359 & 99 & & .105 & .351 \\
Mean_Practicum_Training & Between & 1.675 & 3 & .558 & & \\
& Groups & & & & \\
& Within Groups & 48.479 & 96 & .505 & & \\
& Total & 50.154 & 99 & & & \\
\hline
\end{tabular}




\begin{tabular}{lllllll}
\hline Mean_Mentors_Support & Between & .631 & 3 & .210 & .588 & .624 \\
& Groups & & & & \\
& Within Groups & 34.346 & 96 & .358 & & \\
& Total & 34.977 & 99 & & .622 \\
Mean_Managemental_Suppor & Between & .649 & 3 & .216 & .591 & .622 \\
t & Groups & & & & \\
Within Groups & 35.151 & 96 & .366 \\
& Total & 35.801 & 99 & & \\
\hline
\end{tabular}

Source: Authors

ANOVA analysis in table 9 exhibits there is statistically no significance of mean difference among participants' perceptions ofthe tutoring program based on their level of education. The $\mathrm{p}$-value was greater than $0.05(\mathrm{p}<0.05)$.

\subsubsection{Comparing Participants Perceptions Based on Teacher Department.}

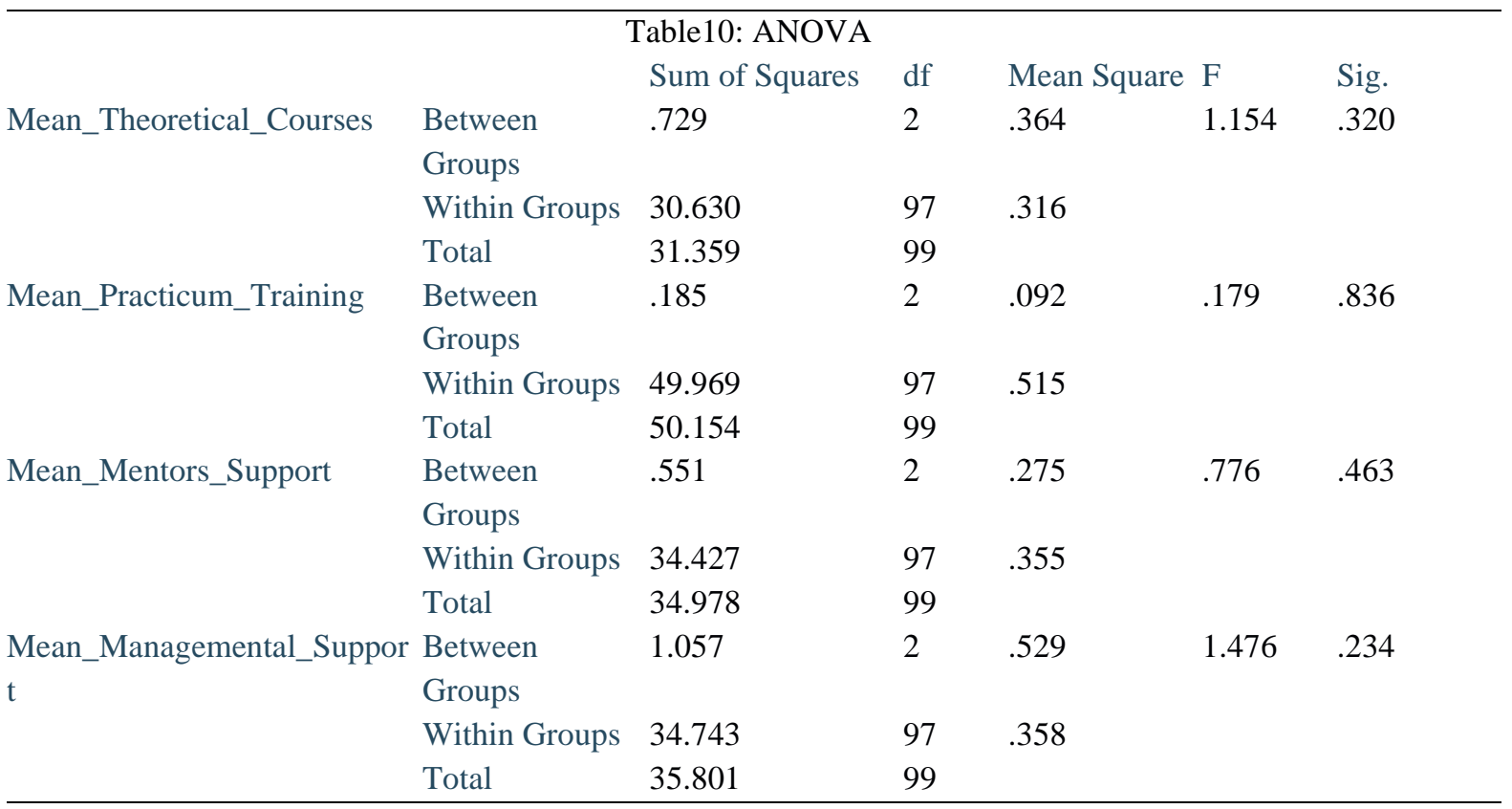

Source: Authors

From the above table10, we observe that ANOVA exposes that there is no significance mean difference among participants' perception of the tutoring program based on teacher department faculties where $\mathrm{p}$ value was above 0.05 .

\section{Discussion}

This work intended to investigate perceptions of pre-service teachers about their tutoring program at teacher college model school to identify whether the college policy of tutoring program is adequately enough to develop pre-service teachers teaching competency to meet the various demands and responsibilities teachers encounter during the teaching process.

\section{Research Question1}


From the descriptive analysis, the researcher found that participants pre-service and inservice teachers $(n=80, n=20)$ perception about the importance of teacher college model theoretical coursework to the development of teaching competency is moderate with mean value 3.56. This means there is a shortage regarding theoretical coursework, most participants' perceptions of teacher college model coursework are positive in term to expand trainees' knowledge regarding the theory of teaching. The current finding goes in line with Dooly \&Sadler (2013) who came up with results explaining that coursework applied to early pre-service education enables teacher trainees to comprehend knowledge for networking theories learned to the practicum training. Interviews exposed a matching result associated with theoretical coursework. Though participants argued elongating duration for theoretical coursework, they admitted the role of coursework to multiply trainees' vision about teaching theories.

Qualitative finding demonstrated there is a significant mean difference among participants' perception of theoretical coursework. The study found that in-service teachers have a high perception of theoretical coursework than pre-service teachers. This indicates that in-service teachers believe theory part is much beneficial for their teaching service. This finding goes in line with (GENC 2016; Erten, 2013) who found teaching theories is identical to in-service teachers to understand various aspects of teaching. Also, the study found that young participants have low perception of theoretical coursework and consider sitting in the class four hours a day is boring and not attractive. From another angle, the study found there is no significance difference of mean difference among participants' perceptions of the theoretical coursework was based on education background or teacher department. This finding could be attributed to the fact that teacher college model's tutoring program is sided much with a theory part. Whether the teacher trainee belongs to scientific departments (Maths, Science, and Physics) or science of Arts department (History, Philology and language), the study found participants have a similar perception towards the tutoring program where $\mathrm{P}$ value was found higher than 0.05 . This finding was validated strongly by the qualitative results where the interviewees complained the load work of theoretical part.

Teacher trainees' perceptions of internship training (practicum sessions) at teacher college model

Based on the descriptive analysis, the study found that trainees of teacher college model have a positive perception towards the internship training. The study substantiated that a host of participants consider their going to the internship training is a better form of education to develop teaching competency. The finding was identical of (Durnali, 2019; Ahemed et al., 2019; Naylor et al., 2015) findings whom uncovered the engagement of pre-service teacher in practicum training is worthwhile to enrich the performance of teacher trainees through what is called "micro-teaching". 
Based on the t-test analysis, the study ascertained that pre-service teacher participants have a high perception of practicum training compared to in-service teachers. Similarly, GENC (2016) found that in-service teachers are not eager for the internship as well as teacher trainees who were identified with high level of tendency to the practicum training. This case could be understood in the term that teacher trainee has more need to rehearse teaching by doing. Erten2013 and Pernsteiner 2015have conjectured that fieldwork is a paramount to flesh out teacher trainee performance. Another finding of the study was also that female participants were identified with low perception of the practicum training compared to their male counterparts. Literature is bared with studies such as (Amankwah et al., 2017; Watt \& Richardson, 2012) demonstrating that female participants prefer the engagement in coursework sessions rather than involved in fieldwork training. From interviews finding, mentors participants emphasized the worthiness of internship training to improve teacher trainees' skills and performance. However, mentor participants were intensified that trainees' passion and attitudes to the profession itself are critical aspects affecting the involvement of teacher trainees in the internship activities. Therefore, Females' perception of the internship is a normal phenomenon that maybe ascribed to the training conditions that are not fairly applicable for female trainees of teacher college model. Also, the study found that there was no significance difference of participants' perception regarding the internship based on level of education or teacher department.

\section{Teacher trainees' perceptions of mentors' support at teacher college model}

Findings on mentors' support displayed that participants had low perceptions of mentors support where the mean score of participants' response regarding this variable was $(M=3.26$, $\mathrm{S}=0.59$ ). This finding entails that participants are not satisfied about the service given by their fellowship mentors though mentoring guideline is a prominent aspect to the development of pre-service teachers. The study finding aligns with (Donkoh \& Dwamena ,2014; Tesfaw \& Hofman, 2012). In contrast, the findings of this study contradict the ones of (Kidd et al., 2015) who underscored a high collaboration of mentors fellowships with their teacher trainees. Again, the study found that female participants' perception of their mentor fellowship was lower than male participants. This finding could be justified from the findings of (Watt \& Richardson, 2012) who argued that female trainees are lugging behind their male counterpart when it comes to the field work activity.

\section{Teacher trainees' perception of management support at teacher college model}

Management or administrative support embodies in this study the role administrators like principals and coordinators instigate to make the tutoring is beneficial for teacher trainees process, and to ensure that educational resources (classes, teachers, supervisors, or mentors) are on viability to assist the trainees. Depended on the overall descriptive analysis implemented to investigate participants' perceptions regarding management support to supplement the tutoring program, the researcher found that participants' perception of the management support is low and the management support has less significant to development 
of teacher trainees with mean 3.28 and standard deviation 0.60. However, the t-test findings indicate there is statistically a mean difference of score among participants' perception of management support based on gender factors. The researcher found that male perceptions of administrative support are high compared with female counterpart. Regarding the discrepancy among female and males' perceptions about the management support, the finding was not surprising as well as the study already got that males perceptions of internship at teacher college model was higher than females one's.

Furthermore, the one-way ANOVA findings report there is statistically a significance of mean difference among participants' perception of management support based on the age group where( $\mathrm{P}>0.05)$. This finding fits with (Cohen, 2014) who found age is a determinant factor to impact perceptions. But the ANOVA results entail there is no significant difference among participants' perceptions of management support based on participants' education background of teacher faculty department where the $P>0.05$. For education background, the $p$ value is $(\mathrm{P}=0.62)$, and the $\mathrm{p}$ value for teacher department faculty was identified with $(\mathrm{P}=$ $0.23)$

\section{Research Question 2}

Aspects facilitate the development of pre-service teachers

Based on findings from the interview, parallelism among the tutoring program, cohesion of relationship to mentors and the profession passionate are major aspects to boost and facilitate the development of pre-service teachers. This finding matches previous literature finding such as (Dawud, 2005; Sina \& Vathiya 2006; \& Kruijer, 2010; Izadinia, 2016; Alkhateeb 2013; \& Andronache et al., 2014). These studies recommended on the balance among coursework and practicum training sessions where teacher trainees find enough time to bridge coursework to teaching practice

\section{Aspects impede the development of pre-service teachers}

Based on mentors' interviews, the researcher found that time restraint, short term of practicum, lack of training resource and the mismatch of the training levels (coursework and internship) are aspects might refrain and hinder the development of pre-service teachers teaching competency. Interviews respondents $(n=2)$ had similar ideas that the mentioned themes are determinant factors to influence pre-service teachers learning and teaching practices. The existing finding aligns with (Durnali ,2019; Demirtas \& Kirbac ,2016; Cocuk et al. 2015) \&, Dalgic et al. 2012) who noted that the short time for internship training is a concerning issue to impact graduate teachers' teaching skills.

\section{Research Question 3}

In-service teachers' perception of theoretical coursework at teacher college model 
The interview respondents $(n=2)$ in-service teachers had a positive perception concerning the benefit of the coursework in terms of educating teacher trainees about teaching theories. However, the in-service participant believed that they spent a long time attending course work classes when they pre-service teachers at teacher college model. This finding implies that participants presume the duration of coursework is too long and has less significance to influence the development of teacher trainees teaching competency. This interview finding is consistent with findings from the survey on the theoretical coursework.

\section{In-service teachers' perception of internship training (practicum) at Teacher College}

Based on the interviews held with in-service teachers to explore their perceptions of practicum session, findings exposed that participants have a privilege assumption that practicum training is more profitable for teacher trainees if they would like to strengthen their teaching performance. Also, this finding complies with quantitative results, which ratified most of the participants were valuing the worthiness of practicum training in terms of increasing their performance for the teaching profession. According to (Pernsteiner 2015), practicum training said to be the primary source to empower candidate teachers with teaching competency, and it is the chance for trainees to put in practice theories and methods learned from the coursework sessions. Thus, the finding from this research complies with the mentioned literature. Again, the researcher found in this study that interview participants had a general opinion about the mismatch among levels of teacher college model's tutoring program. The finding contradicts findings concluded by Andromache et al. (2014), who stressed the importance of equalizing the level of coursework with practicum training level to finer the competency of candidate teachers.

Despite quantitative results showed in-service teachers with high trend to theoretical coursework as was compatible with findings from GENEC (2016). In-service teacher participants for interviews complained about the duration offered to pre-service teachers to perform up field teaching practices. Accordingly, the finding phrases that the initiatives of teacher college model are essential required to review the internship duration encompassed in the teacher college model tutoring program. Opinions suggested on this issue from in-service teachers claimed the practicum limitation time to four weeks is not plenty enough for teacher trainees to improve teaching competency. Then, expanding practicum duration from four weeks to a maximum of eight weeks of intensive internship training would add more values to better trainee teachers teaching skills.

In-service teachers' perceptions of mentors and management support at teacher college model

First of all, in-service teacher participants $(n=2)$ were required to express their views on facilitators they received from mentors as a support to strengthen the development of their teaching competency when they were candidate teachers at teacher college model. Results from the interview sections showed varying findings among respondents who agreed to 
participate in the interview process. Imaginably, the inconsistency views among $(n=2)$ inservice teacher participants term the qualitative results on mentors' support. The overall mean across participants $(n=100)$ was $M=3.26$, with $S=0.59$. One participant out of $(n=2)$ emphasized inbounding contact with the mentor, who was in charge of him. The current findings replicate the ones from Kidd et al. (2015), who summarized that mentors' engagement in other occupation causes a gape contact between mentors and trainee teachers because mentors would not have enough time to assist frequently the trainees at teacher schools. The finding matches literature such as Buchanan et al. (2013) who confessed the central part for mentors is to further the teaching competency for candidate teachers through the lively support mentors provide during the preparation program. Based on the interview findings, the research signifies that mentors' effort to help teacher trainees varies among Teacher College mentors. Lack of measures to evaluate mentors support might be a source makes mentors not to perform their responsibilities properly. Findings on the issue of mentors support propose to the administrators of teacher college model to set up mentoring rules to evaluate the mentoring process during the tutoring program accordingly.

Based on qualitative results, the researcher interpreted factors like the absence of workshops and seminars for mentors and teacher trainees as major themes participants suggest that teacher college model management has to rethink about and rearrange the policy regarding it accordingly. Regarding in-service teachers' perception of the management support, findings revealed that there is an agreement among in-service participants on the management deficit in terms of the support allocated to sustain the development of pre-service teachers teaching performance. Likewise, findings of Amankwah et al. (2017) who found that the management shortage is among factors challenging the development of pre-service teachers. Therefore, participants hoped that teacher college model revise strategies to develop the tutoring quality for which in turn will affect the development of teacher trainees.

\section{Conclusion and Suggestion}

Based on the results derived from the survey questionnaire and semi-structured interviews, the researcher comes up with the following conclusions:

a. Teacher college model tutoring program is strongly affecting pre-service teachers to learn theory of teaching. Theoretical coursework is much dominating the preparation program which makes it basically to be a theory content-oriented.

b. Practicum or internship training has a significant impact on pre-service teachers teaching competency. However, the short term of internship training sessions is not adequately enough for teacher trainees to learn and assimilate teaching practices. Therefore, the short term of practicum training is a matter of concern participants of the study complained.

c. There is mismatching between theoretical coursework and internship training session where teacher trainees spend more time attending coursework. This affects the duration of the internship training. Though findings showed the majority of participants prefer the internship training session for the sake to improve their 
teaching performance, still teacher trainees do not get that much chance for the practicum training because of the overload of theoretical coursework sessions. Consequently, teacher college model is in a dire need to adjust the levels of preservice teachers tutoring program to make the program is practicable for the development of pre-service teachers teaching competency.

d. Lack of measures to evaluate and observe mentors' support of the teacher trainees during the field training sessions.

e. Administration absenteeism in the area of organizing training sessions and workshops on the mentoring profession for the improvement of mentor skills, which in turn could affect the development of teacher trainees.

\section{Recommendations}

Based on the findings, the study suggested the following recommendations;

- Teacher College Model has to adjust levels of its tutoring where it was found that teacher trainees suffer the short term of practicum while they are complaining the workload of coursework.

- Simplify conditions of internship, so all teacher trainees can have equal access to fieldwork training. Quantitative results displayed female teacher trainees with a low impression of field training.

- Another way of assessment regarding teacher college model tutoring program could be including observation. So, the study suggests a qualitative study to be conducted to observe different aspects of the tutoring program.

N/B: Teacher College Model is a pseudonym used by the authors to refer to the institution where the study was done.

\section{Conflict of Interest}

The authors of the article declare no conflict of interest.

\section{Funding}

This research study was not funded by any institution. The author conducted the study on their own expenses.

\section{References}

Ahmed, I et al. (2019). Impact of microteaching on prospective teachers' performance. Department of Education, Hazar University, Dhodial, Pakistan. WALIA journal 35(1):33-38,2019 ISSN1026-3861

Alkhateeb, H. M. (2013). Attitudes towards teaching profession of education students in Qatar. Comprehensive Psychology. doi: 10.2466/01.03. IT.2.9 
Alsup. J. (2006) Teacher identity discourses: Negotiating personal and professional spaces. Hillsdale, NJ: Lawrence Erlbaum Associates.

Amankwah, P. O. A., \& S, F.K. (2017). Perceptions of Pre-service Teachers` Toward the Technology Practice Program in College of Technology Education, University of Education, Winneba. Journal of Education and Practice. ISSN 2222-1735(paper) ISSN 2222-288. Vol.8, No 4, 2017

Andronache, D., Bocos, M., Bocos, V., \& Macri, C. (2014). Attitude towards teaching profession. Procedia-Social and Behavioral Sciences, 142, 628-632. doi: 10.1016/j.sbspro.2014.07.677

Buchanan, J et., al. (2013). Teacher retention and attrition: Views of early career teachers. Australian Journal of Teacher Education, 38(3). http://dx.doi.org/10.14221/ajte.2013v38n3.9

Çocuk, H. E., Yokuş, G., \& Tanrıseven, I. (2015). Pedagogical formation students's selfefficacy and metaphoric perceptions related to teaching profession. Mustafa Kemal University Journal of Graduate School of Social Sciences, 12(32), 373-387.

Cohen, A. (1993). Age and tenure in relation to organizational commitment: A metaanalysis. Basic and applied social psychology, 14(2), 143-159.

Creswell, J. W. (2014a). Research design: qualitative, quantitative and mixed methods aproches. $4^{\text {th }}$ ed. Library of Congress Cataloging-in-Publication Data. SAGE Publications, Inc

Dalgıç, G., Doyran, F., \& Vatanartıran, S. (2012). Experiences of hourly paid teachers on the teacher certification program. Ücretli ögretmenlerin, katıldıklarl pedagojik formasyon programina ilişkin deneyimleri) Mediterranean Journal of Educational Research, 11, 39-54.

Darling-Hammond, L., \& Bransford, J. (Eds.). (2007). Preparing teachers for a changing world: What teachers should learn and be able to do. John Wiley \& Sons.

Dawud, B. (2005). The Ideal Education Curricula. Arabic Printing Press, Algeria Department of Education.

Demirtas, H., \& Kirbac, M. (2016). The views of pedagogic formation certificate program students regarding pedagogic formation training. Trakya University Journal of Education, 6(2), 138-152.

Esia-Donkoh, K., \& Ofosu-Dwamena, E. (2014). Effects of educational supervision on professional development: Perception of public basic school teachers at Winneba, Ghana. British Journal of Education, 2(6), 63-82.

Dooly, M., \& Sadler, R. (2013). Filling in the gaps: Linking theory and practice through telecollaboration in teacher education. ReCALL: the Journal of EUROCALL, 25(1), 4.

Filiz, B., \& Durnali, M. (2019). The Views of Pre-Service Teachers at an Internship High School on Pedagogical Formation Program in Turkey. European Journal of Educational Research, 8(2), 395-407.

Eret, E. (2013). An assessment of pre-service teacher education in terms of preparing teacher candidates for teaching. Unpublished doctoral dissertation. Middle East Technical University, Ankara. 
Genç, Z. S. (2016). More practice for pre-service teachers and more theory for in-service teachers of English language. Procedia-Social and Behavioral Sciences, 232, 677683.

Hattie, J. A. C. (2009). Visible learning: A synthesis of over 800 meta-analyses relating to achievement. London: Rutledge.

Izadinia, M. (2016). An investigation into mentor teacher-preservice teacher relationship and its contribution to development of preservice teachers' professional identity. Retrieved from https://ro.ecu.edu.au/theses/1792

Katitia, D. M. O. (2015). Teacher Education Preparation Program for the 21st Century. Which Way Forward for Kenya?. Journal of Education and Practice, 6(24), 57-63.

Kidd, L., Brown, N., \& Fitzallen, N. (2015). Beginning teachers' perception of their induction into the teaching profession. Australian journal of teacher education, 40(3), 10.

Kruijer, H. (2010). Learning how to teach, the upgrading of unqualified primary teachers in sub-Saharan Africa: Lessons from Tanzania. Malawi and Nigeria', Brussels: Education International.

Lave, J., \& Wenger, E. (1991). Situated learning: Legitimate peripheral participation. Cambridge university press.

Ministry of Higher Education.(2018). The government of Mauritania; Nouakchott. Mauritania.

Naylor, D. (2010). Learning to Teach; What do Pre-Service Teachers Report?. eCULTURE, 3(1), 7.

Sinya, B., \& S. Vethiya. (2006). Evaluation of preservice teachers training programs. Teachers Education Colleges; Algeria.

Sinyolo, D. (2007). Teacher supply, recruitment and retention in six Anglophone subSaharan African Countries: A report on a survey conducted by Education International in The Gambia, Kenya, Lesotho, Tanzania, Uganda and Zambia. Education International.

Palardy, G. J., \& Rumberger, R. W. (2008). Teacher effectiveness in first grade: The importance of background qualifications, attitudes, and instructional practices for student learning. Educational Evaluation and Policy Analysis, 30(2), 111-140.

Pernsteiner, A. J. (2015). The Value of an Accounting Internship: What Do Accounting Students Really Gain?. Academy of Educational Leadership Journal, 19(3), 223.

Tesfaw, T. A., \& Hofman, R. H. (2012). Instructional Supervision and Its Relationship with Professional Development: Perception of Private and Government Secondary School Teachers in Addis Ababa. Online Submission.

UNESCO. (2016). World Teachers Day. Retrieved 5 May 2018 from https://news.un.org/en/story/2016/10/541902

Watt, H. M., Richardson, P. W., \& Devos, C. (2013). (How) does gender matter in the choice of a STEM teaching career and later teaching behaviours?. International journal of gender, science and technology, 5(3), 187-206. 